\title{
Postmodern Proust
}





\section{Postmodern Proust}

Margaret E. Gray 
Copyright $\mathbb{1} 1992$ by the University of Pennsylvania Press

All rights reserved

Printed in the United States of America

Library of Congress Cataloging-in-Publication Data

Gray, Margaret E.

Postmodern Proust / Margaret E. Gray.

p. $\quad \mathrm{cm}$.

Includes bibliographical references and index.

ISBN 0-8122-3149-X

1. Proust, Marcel, 1871-1922. A la recherche du temps perdu.

2. Postmodernism (Literature)-France. I. Title.

PQ2631.R63A795 1992

$843^{\prime} .912-\mathrm{dc} 20$ 